\title{
Pertumbuhan Kuantitatif Anakan Murai Batu Hingga Fase Ranggas Bulu Pertama
}

\author{
Quantitative Development of White-Rumped Shama Chick Reared until the First \\ Moulting Stage
}

\author{
H. D. Putranto ${ }^{1}$, B. Brata ${ }^{1}$, dan Y. Yumiati ${ }^{2}$ \\ 1) Jurusan Peternakan Fakultas Pertanian Universitas Bengkulu \\ ${ }^{2)}$ Program Studi Agribisnis Fakultas Pertanian Universitas Dehasen Bengkulu \\ Corresponding e-mail: heri_dp@unib.ac.id
}

\begin{abstract}
Among Indonesian especially in Bengkulu city, white-rumped shama (Copsychus malabaricus) had been choosen as one of favorite pet since past two decades. We found that number of bird keepers in Bengkulu also managed to do hatching of eggs and bird chick rearing management. However, it was not easy to keep a chick survive when it separated from parent. This study aims to explore a weekly fundamental data on white-rumped shama quantitative development of body length, wing length and feet length during a rearing period of 30-days of age until first moulting stage. All data were analysed descriptively. Research results showed that mixed sex white-rumped shama chicks body length varied between $44.9 \mathrm{~mm}$ to $52.18 \mathrm{~mm}$ averaged $49.546 \mathrm{~mm} /$ chick, wing length varied between $100.42 \mathrm{~mm}$ to $115.48 \mathrm{~mm}$ averaged $107.24 \mathrm{~mm} / \mathrm{chick}$, and feet length varied between $50.2 \mathrm{~mm}$ to $53.2 \mathrm{~mm}$ averaged $51.45 \mathrm{~mm} /$ chick. It can be concluded that mixed sex white-rumped shama chick's body, wing and feet length were developed quantitatively during its 30-days of age until its first moulting stage.
\end{abstract}

Key words: chick, moulting, quantitative development, white-rumped shama.

\begin{abstract}
ABSTRAK
Murai batu (Copsychus malabaricus) telah menjadi salah satu pilihan penghobi burung di Indonesia sejak dua puluh tahun terakhir, termasuk di Kota Bengkulu. Para penghobi burung telah mulai melakukan beberapa langkah konservasi biologi antara lain dengan melakukan upaya penetasan dan pemeliharaan anakan. Anakan murai batu dikenal cukup sulit untuk dipelihara dan akan mudah mati apabila dipisahkan dari induknya, sehingga sampai saat ini belum banyak diketahui tentang ukuran morfometriknya. Penelitian ini bertujuan untuk mengeksplorasi data fundamental pertumbuhan kuantitatif badan, sayap dan kaki anakan burung murai batu kelamin campuran selama pemeliharaan ex situ mulai umur 30 hari hingga fase ranggas bulu pertama. Koleksi data dilakukan dengan metode observasi dan pengukuran panjang badan, panjang sayap dan panjang kaki setiap minggu. Data kemudian dianalisis secara deskriptif. Hasil penelitian menunjukkan bahwa panjang badan anakan murai batu kelamin campuran bervariasi antara $44,9 \mathrm{~mm}$ sampai $52,2 \mathrm{~mm}$ dengan rata-rata 49,56 $\mathrm{mm} /$ ekor, panjang sayap antara 100,4 mm sampai $115,5 \mathrm{~mm}$ dengan rata-rata $107,25 \mathrm{~mm} /$ ekor, dan panjang kaki antara $50,2 \mathrm{~mm}$ sampai $53,2 \mathrm{~mm}$ dengan rata-rata $51,45 \mathrm{~mm} /$ ekor. Dapat disimpulkan bahwa terjadi pertambahan ukuran kuantitatif (panjang badan, panjang sayap dan panjang kaki) anakan murai batu hingga fase ranggas bulu pertama.
\end{abstract}

Kata kunci: anakan, kuantitatif, murai batu, pertumbuhan, ranggas bulu.

\section{PENDAHULUAN}

Bagi para penghobi burung di nusantara, istilah anakan atau trotol adalah kosakata yang digunakan untuk menyebut individu anak burung. Untuk penghobi atau pemelihara burung murai batu (Copsychus malabaricus), anakan diartikan sebagai anak burung murai batu yang berumur 12 sampai 14 hari atau sampai belum berganti bulu dewasa (Putranto et al., 2020b). Secara umum diketahui bahwa anakan burung murai batu akan mengalami ranggas bulu pertama kalinya pada umur 4 sampai 5 bulan (Gambar 1).

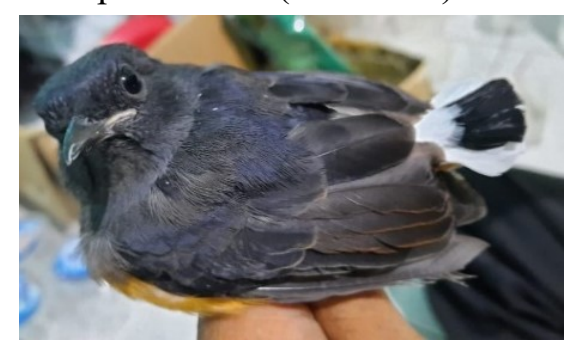

Gambar 1. Profil anakan burung murai batu 
Sampai saat ini, penghobi burung murai batu di Kota Bengkulu menemukan beberapa masalah saat melakukan pemisahan anakan dari induknya (Brata et al., 2019, Putranto et al., 2018; 2019 a,b; 2020a,b). Masalah utamanya adalah apabila dilakukan upaya pemisahan/penyapihan paksa, maka akan memunculkan peningkatan level cekaman pada anakan yang ditandai dengan hilangnya nafsu makan (appetite) anakan yang dapat berakibat fatal berupa mortalitas. Diperkirakan, anakan masih belum bisa makan sendiri atau masih dilolohkan oleh induknya. Tindakan penyapihan/pemisahan anakan dari induknya masih belum menjadi prioritas dalam pemeliharaan burung murai batu.

Fase hidup burung selanjutnya adalah sebuah tahapan pergantian atau luruhnya bulu dari tubuh. Fase pergantian bulu ini juga dikenal dengan istilan ranggas bulu atau moulting (Putranto et al., 2020b). Ranggas bulu atau moulting adalah proses perontokan atau pergantian bulu-bulu yang terjadi pada burung, ayam, serta unggas berbulu lainnya dan biasanya burung dan unggas akan mengalami masa ranggas bulu 1 tahun sekali secara periodik. Untuk murai batu, biasanya anakan mulai berganti bulu pada umur sekitar 4 - 5 bulan .

Seiring dengan kesadaran masyarakat akan upaya konservasi dalam hal ini upaya menjaga populasi plasma nutfah di habitat in situ, dalam kondisi tertentu beberapa penghobi dan penangkar burung murai batu telah memulai upaya potensial yang mengarah pada tindakan pelestarian (Putranto et al., 2020a,b). Upaya potensial tersebut antara lain adalah penetasan dan penyapihan yang dilakukan sesuai dengan kesepakatan antara pemilik/penangkar burung dengan calon pembeli anakan burung walaupun ada resiko yang besar.

Hingga saat ini, masih banyak informasi biologi burung murai batu yang belum diketahui secara pasti. Kendala berupa sulitnya melakukan penyapihan, tindakan khusus berupa menyuapi dalam aktifitas makan sampai level cekaman yang tinggi menyebabkan anakan murai batu jarang dipelihara terpisah sehingga membuat terbatasnya informasi ukuran morfometriknya. Penelitian ini bertujuan untuk mengeksplorasi data fundamental pertumbuhan kuantitatif panjang badan, panjang sayap dan panjang kaki anakan burung murai batu kelamin campuran selama pemeliharaan ex situ mulai umur 30 hari hingga fase ranggas bulu pertama.

\section{MATERI DAN METODE}

Sebanyak 8 ekor anakan murai batu berjenis kelamin campuran (mixed sex) yang berasal dari satu peternak yang sama dengan jenis persilangan antara Medan $\mathrm{x}$ Bengkulu Utara dipergunakan dalam penelitian ini. Anakan memiliki umur yang sama (30 hari) dengan berat badan yang bervariasi, dan kondisi kesehatan yang baik. Pakan yang diberikan berupa kombinasi voer dan kroto yang dilolohkan sekali sehari serta air minum ad libitum.

Adapun kandungan nutrisi dalam kroto yaitu larva dan pupa berupa kalori 493 kkal, kadar air $22 \%$, protein $24,1 \mathrm{~g}$, lemak $42,2 \mathrm{~g}$, karbohidrat 4,3 g, serat 4,6 g, abu 2,8\%, kalsium $40 \mathrm{mg}$, fospor $230 \mathrm{mg}$, besi $10,4 \mathrm{mg}$, vitamin A $710 \mathrm{IU}$, vitamin B1 0,22 0,22 $\mathrm{mg}$, vitamin B2 $1,13 \mathrm{mg}$ dan niacin 5,7 mg (Prayoga, 2015; Putranto et al., 2020b). Kandungan nutrisi pada voer antara lain protein minimal 19\%, lemak minimal 3\%, serat maksimal 9\% dan kadar air maksimal 12\% (Anonim, 2019).

Seperti yang dilaporkan dalam penelitian sebelumnya (Putranto et al., 2020b), alat yang digunakan dalam penelitian ini adalah sangkar yang berbentuk umbaran dengan panjang $200 \mathrm{~cm}$, lebar $50 \mathrm{~cm}$, tinggi $175 \mathrm{~cm}$ dan tinggi tiang sangkar $25 \mathrm{~cm}$. Tiap sangkar dilengkapi dengan tempat pakan dan minum, tempat mandi burung, dan tempat bertengger. Alat lainnya yang dipergunakan adalah penggaris besi $30 \mathrm{~cm}$, alat tulis, sprayer, kamera dan jangka sorong digital (electronic digital caliper) ketelitian 0,001 mm produksi Qingdao Tide Machine Tool Supply Co, Ltd.

Penelitian telah dilakukan selama 6 bulan dimulai pada tanggal 01 September 2019 tanggal 29 Februari 2020 di Kota Bengkulu. Penelitian dilakukan secara observasi dengan pengukuran parameter morfometrik anakan murai batu setiap minggu. Koleksi data dilakukan melalui pengamatan secara langsung anakan murai batu yang dipelihara. Parameter pertumbuhan kuantitatif yang diamati adalah:

\section{Panjang Badan}

Pengukuran panjang badan anakan murai batu kelamin campuran diukur menggunakan jangka sorong digital dengan satuan $(\mathrm{mm})$. Metode pengukuran mengikuti Jull (1951), yaitu diukur mulai dari pangkal leher hingga pangkal ekor burung. 


\section{Panjang Sayap}

Pengukuran panjang sayap anakan murai batu kelamin campuran diukur menggunakan jangka sorong digital dengan satuan (mm). Metode pengukuran merujuk pada Lambey (2013), diukur mulai dari pangkal sayap hingga ujung bulu sayap burung tanpa penekanan (Gambar 2).

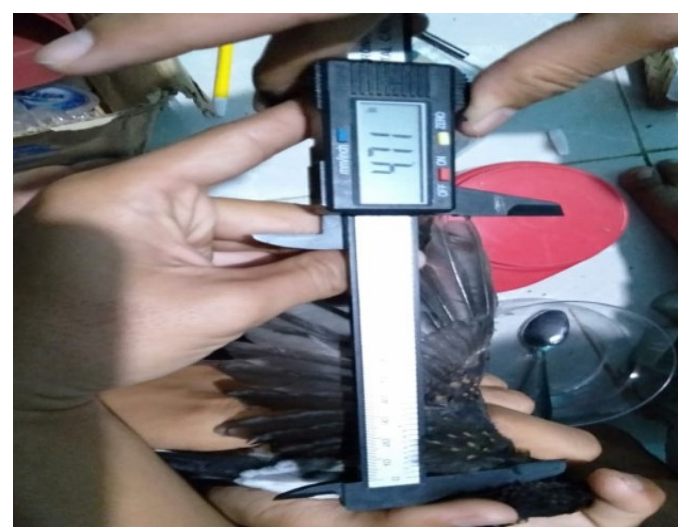

Gambar 2. Pengukuran panjang sayap

\section{Panjang Kaki}

Pengukuran panjang kaki anakan murai batu kelamin campuran diukur menggunakan jangka sorong digital dengan satuan ( $\mathrm{mm})$. Metode pengukuran mengikuti Jull (1951), diukur mulai dari pangkal paha atau femur sampai ujung tulang kering atau tibia.

Data yang diperoleh ditabulasi, dan disajikan dalam bentuk tabel kemudian dibahas secara deskriptif.

\section{HASIL DAN PEMBAHASAN}

Peneliti meyakini bahwa informasi pertumbuhan kuantitatif anakan murai batu $(C$. malabaricus) ini adalah artikel ilmiah pertama yang menampilkan data morfometrik anakan murai batu kelamin campuran yang dipelihara pada habitat ex situ. Secara umum, masih dipercaya bahwa terdapat beberapa perbedaan antara pertumbuhan kuantitatif individu yang hidup secara alami pada habitat in situ dan individu yang dipelihara pada habitat ex situ dengan modifikasi lingkungan.

Hasil penelitian pertumbuhan kuantitatif panjang badan, panjang sayap dan panjang kaki anakan burung murai batu kelamin campuran selama penelitian dapat dilihat pada Tabel 1 berikut. Data hasil penelitian menunjukkan bahwa panjang badan anakan murai batu kelamin campuran memiliki ukuran yang berbeda-beda. Pada setiap minggu umur ranggas bulu didapati panjang badan anakan murai batu kelamin campuran bervariasi antara $44,9 \mathrm{~mm}$ sampai 52,2 $\mathrm{mm}$ dengan rata-rata $49,56 \mathrm{~mm} / \mathrm{ekor}$. Peneliti berasumsi bahwa perbedaan ukuran panjang badan anakan murai batu kelamin campuran diakibatkan adanya faktor genetik, jenis kelamin dan pakan.

Selanjutnya, data hasil penelitian pada Tabel 1 juga memperlihatkan bahwa pada setiap minggu umur ranggas bulu didapati panjang sayap anakan burung murai batu kelamin campuran bervariasi antara terendah 100,4 mm sampai tertinggi $115,5 \mathrm{~mm}$ dengan rata-rata $107,25 \mathrm{~mm} /$ ekor. Perbedaan umur ranggas bulu menyebabkan pencapaian pertumbuhan ukuran panjang sayap yang berbeda untuk setiap individu anakan burung murai batu. Peneliti berasumsi bahwa hal ini juga disebabkan juga oleh faktor genetik, pakan dan faktor lingkungan sebagaimana perbedaan panjang badan sebelumnya.

Lebih jauh lagi, pada Tabel 1 data hasil penelitian memperlihatkan pertumbuhan kuantitatif panjang kaki anakan burung murai batu kelamin campuran selama penelitian yang memiliki tren yang serupa dengan pertumbuhan kuantitatif panjang badan dan panjang sayap.

Dapat dilihat bahwa panjang kaki anakan murai batu kelamin campuran hingga fase ranggas bulu pertama selama penelitian diketahui berbeda-beda baik dalam ukuran panjang ataupun waktu ranggas bulunya. Pada setiap minggu umur ranggas bulu didapati panjang kaki anakan burung murai batu kelamin campuran bervariasi antara 50,2 $\mathrm{mm}$ sampai $53,2 \mathrm{~mm}$ dengan ratarata $51,45 \mathrm{~mm} / \mathrm{ekor}$.

Menurut Putranto et al., (2020b) ranggas bulu atau bulu rontok pertama diasumsikan sebagai tanda utama molting atau mabung pada burung murai batu. Sedangkan mabung atau molting diartikan sebagai proses perontokan atau pergantian bulu-bulu yang terjadi pada burung biasanya dengan frekuensi 1 tahun sekali secara periodik. Hasil studi eksploratif yang dilakukan Putranto et al. (2020b) sebelumnya, diketahui bahwa ke-8 anakan murai batu kelamin campuran yang diamati mengalami ranggas bulu pertama pada umur pemeliharaan dan umur biologis yang bervariasi. 
Tabel 1. Pertumbuhan kuantitatif panjang badan, panjang sayap, dan panjang kaki anakan murai batu kelamin campuran mulai umur 30 hari hingga fase ranggas bulu pertama.

\begin{tabular}{|c|c|c|c|c|c|c|c|c|c|c|c|c|c|c|c|c|c|c|c|c|c|c|c|c|}
\hline \multirow{3}{*}{$\begin{array}{c}\text { Minggu } \\
\text { Ke- }\end{array}$} & \multicolumn{24}{|c|}{ Pertumbuhan Kuantitatif Anakan Murai Batu kelamin Campuran } \\
\hline & \multicolumn{8}{|c|}{ PB } & \multicolumn{8}{|c|}{ PS } & \multicolumn{8}{|c|}{ PK } \\
\hline & A1 & A2 & A3 & A4 & A5 & A6 & A7 & $\mathbf{A 8}$ & A1 & A2 & A3 & A4 & A5 & A6 & A7 & A8 & A1 & A2 & A3 & A4 & A5 & A6 & A7 & A8 \\
\hline \multicolumn{25}{|c|}{----- mm/ekor ------ } \\
\hline 1 & 46,9 & 40,5 & 46,3 & 46,9 & 49 & 42,2 & 40,8 & 48,7 & 90,5 & 89,9 & 90,9 & 90,5 & 95,5 & 92,5 & 92,3 & 90,6 & 49,9 & 49,7 & 49,8 & 49,9 & 50 & 49,7 & 49,8 & 49,2 \\
\hline 2 & 50 & 50,1 & 49,9 & 50 & 47,5 & 45,2 & 44,1 & 49,2 & 98,5 & 90,9 & 96,5 & 98,5 & 99 & 95,9 & 95,6 & 96,4 & 49,9 & 49,8 & 49,8 & 49,9 & 50,1 & 49,9 & 50 & 49,8 \\
\hline 3 & 50,1 & 50,1 & 50 & 50,1 & 49,2 & 47,5 & 44,8 & 50 & 101,4 & 101,2 & 101,3 & 101,4 & 103,4 & 102,2 & 102,1 & 102,1 & 50 & 50,1 & 50 & 50 & 50,1 & 50,2 & 50,4 & 50,1 \\
\hline 4 & 50,2 & 51,3 & 50,4 & 50,2 & 50,2 & 50 & $49,9^{*}$ & 50,4 & 101,8 & 101,6 & 103,7 & 101,8 & 104,2 & 103,1 & $111,7^{*}$ & 103,2 & 50,1 & 50,3 & 50,5 & 50,1 & 50,2 & 50,4 & $50,6^{*}$ & 50,3 \\
\hline 5 & 50,4 & 52,3 & 51,3 & 50,4 & 51,1 & $50,5^{*}$ & & $50,9^{*}$ & 113 & 112,9 & 116,9 & 113 & 122,2 & $120,2^{*}$ & & $120 *$ & 52,1 & 51,3 & 51,2 & 52,1 & 51,7 & $51,6^{*}$ & & $51,8^{*}$ \\
\hline 6 & 50,4 & 52,4 & 52,3 & 50,4 & 54,4 & & & & 121,2 & 120,3 & 118,4 & 121,2 & 124,3 & & & & 54,9 & 52,3 & 52,5 & 54,9 & 53,2 & & & \\
\hline 7 & $51,5^{*}$ & 52,8 & 52,6 & 51,5 & 54,6 & & & & $123 *$ & 120,6 & 122,1 & $123^{*}$ & 125,3 & & & & $55^{*}$ & 52,5 & 52,9 & $55^{*}$ & 55,1 & & & \\
\hline 8 & & 52,9 & 52,8 & $51,5^{*}$ & 54,6 & & & & & 123,2 & 122,9 & & 125,7 & & & & & 53,2 & 53 & & 55,3 & & & \\
\hline 9 & & 53,1 & 52,8 & & 55,5 & & & & & 123,5 & 123,1 & & 127,1 & & & & & 55,2 & 54,5 & & 57,4 & & & \\
\hline 10 & & $54,2^{*}$ & $55,1^{*}$ & & $55,7^{*}$ & & & & & $124^{*}$ & $124^{*}$ & & $128,1^{*}$ & & & & & $57,9^{*}$ & $55,5^{*}$ & & $58,9^{*}$ & & & \\
\hline Total & 349 & 510 & 513 & 401 & 522 & 235 & 180 & 249 & 749 & 1108 & 1119 & 749 & 1155 & 514 & 402 & 512 & 362 & 522 & 520 & 362 & 532 & 252 & 201 & 251 \\
\hline Rerata & 49,9 & 50,9 & 51,3 & 50,1 & 52,2 & 47,1 & 44,9 & 49,8 & 107 & 110,8 & 111,9 & 107 & 115,5 & 102,8 & 100,4 & 102,5 & 51,7 & 52,2 & 51,9 & 51,7 & 53,2 & 50,4 & 50,2 & 50,2 \\
\hline $\begin{array}{c}\text { Rerata/ } \\
\text { ekor }\end{array}$ & \multicolumn{8}{|c|}{49,55} & \multicolumn{8}{|c|}{107,25} & \multicolumn{8}{|c|}{51,45} \\
\hline & Ketera & gan: & $\begin{aligned} \mathrm{PB} & =\mathrm{F} \\
\mathrm{PS} & =\mathrm{F} \\
\mathrm{PK} & =1 \\
\mathrm{~A} 1 & = \\
\mathrm{A} 2 & = \\
\mathrm{A} 3 & = \\
\mathrm{A} 4 & = \\
\mathrm{A} 5 & = \\
\mathrm{A} 6 & = \\
\mathrm{A} 7 & = \\
\mathrm{A} 8 & = \\
* & =\end{aligned}$ & $\begin{array}{l}\text { anjang } \\
\text { anjang } \\
\text { anjang } \\
\text { nakan } \\
\text { nakan } \\
\text { nakan } \\
\text { nakan } \\
\text { nakan } \\
\text { nakan } \\
\text { nakan } \\
\text { nakan } \\
\text { Jaktu r }\end{array}$ & $\begin{array}{l}\text { Badan } \\
\text { Sayap } \\
\text { Kaki } \\
\text { murai } \\
\text { murai } \\
\text { murai } \\
\text { murai } \\
\text { nurai } \\
\text { murai } \\
\text { nurai } \\
\text { murai } \\
\text { inggas }\end{array}$ & $\begin{array}{l}\text { atu no } \\
\text { atu no } \\
\text { atu no } \\
\text { atu no } \\
\text { atu no } \\
\text { atu no } \\
\text { atu no } \\
\text { atu no } \\
\text { bulu p }\end{array}$ & $\begin{array}{l}\text { nor } 1 \\
\text { nor } 2 \\
\text { nor } 3 \\
\text { nor } 4 \\
\text { nor } 5 \\
\text { nor } 6 \\
\text { nor } 7 \\
\text { nor } 8 \\
\text { rtama }\end{array}$ & & & & & & & & & & & & & & & & & \\
\hline
\end{tabular}


Hasil studi terdahulu didapatkan data bahwa rata-rata ranggas bulu pertama anakan murai batu kelamin campuran terjadi pada umur pemeliharaan 7,25 minggu (umur biologi 80,75 hari) dengan rentang waktu umur pemeliharaan 4 - 10 minggu atau umur biologi anakan murai batu antara 58 - 100 hari. Selanjutnya, disebutkan pula oleh Putranto et al. (2020b) dari ke-8 anakan murai batu kelamin campuran dalam penelitian ini, umur ranggas bulu pertama tercatat paling cepat pada umur pemeliharaan 4 minggu (umur biologi 58 hari) dan paling lambat pada umur pemeliharaan 10 minggu (umur biologi 100 hari).

Menurut Anonim (2020a), burung yang masih berusia muda atau anakan mengalami pertumbuhan dengan cepat jika dibarengi dengan pemberian protein yang cukup dalam pakan yang diberikan. Hal ini senada dengan pendapat Anggorodi (1995) menyatakan bahwa setiap pertumbuhan pada tulang, jaringan otot, organ internal dan bagian tubuh lainnya, protein dalam pakan menjadi salah satu komponen yang penting dalam pertumbuhan. Disebutkan pula bahwa pemberian protein dalam jumlah $20 \%$ saja sudah cukup untuk pertumbuhan anakan. Pada penelitian ini anakan murai batu diberikan pakan berupa kombinasi voer dan kroto yang diasumsikan bergizi cukup tinggi. Adapun kandungan protein dalam kroto mencapai $24,1 \mathrm{~g}$ dan nilai ini sudah lebih tinggi dibandingkan pendapat sebelumnya yang hanya menyarankan jumlah 20\%.

Hasil studi terdahulu dari Hickman et al. (2007) tentang sayap pada burung, dinyatakan bahwa sayap pada burung memiliki ukuran yang berbeda-beda karena menyesuaikan antara tubuh burung dengan habitatnya. Burung memiliki sepasang sayap dan tubuhnya ditutupi oleh bulu yang berfungsi sebagai pelindung tubuh serta mempengaruhi daya terbang (Radiopoetro, 1986).

Tulang-tulang di sayap sangat ringan sehingga burung bisa terbang lebih mudah. Burung memiliki tulang-tulang yang khas yang sesuai untuk terbang. Anggota depan berubah fungsi menjadi sayap. Tulang sayap dan kaki memiliki banyak tulang yang berongga yang saling bersilang untuk menambah kekuatan struktur tulang. Tulang sayap relatif panjang dan luas permukaan sayap berhubungan untuk menghasilkan beban sayap yang rendah (Saraswati et al., 2018).

Secara umum, menurut Anonim (2020b), kaki burung diklasifikasikan menjadi anisodactyl, zygodactyl, heterodactyl, syndactyl atau pamprodactyl. Anisodactyl merupakan bentuk kaki burung yang paling umum, dengan tiga jari di depan dan satu di belakang. Bentuk seperti ini banyak ditemui di burung penyanyi, burung pengicau, elang, rajawali, dan falkon. Burung murai batu tergolong dalam burung penyanyi.

Untuk panjang kaki burung Jull (1951) menulis bahwa kaki burung diasumsikan terdiri atas panjang paha yang merupakan panjang tulang femur yaitu dari persendian tulang pangkal paha sampai dengan persendian pangkal atas tulang tibia. Hasil penelitian tentang panjang kaki anakan burung murai batu berkelamin campuran memiliki ukuran yang bervariasi. Perbedaan ini diasumsikan akibat dari perbedaan jenis kelamin, genetik dan pakan yang diberikan.

Prayoga (2015) menyatakan komponen yang terdapat dalam kroto yaitu larva dan pupa terdapat kandungan gizi Vit A sebesar 710 (IU) yang dianggap tinggi. Ditambahkan oleh pendapat dari Rose (1997) yang menyatakan bahwa pertumbuhan tulang lebih banyak diatur oleh faktor genetik dan hormon serta vitamin D dan A.

\section{KESIMPULAN}

Berdasarkan hasil penelitian ini dapat disimpulkan bahwa terjadi pertambahan ukuran kuantitatif (panjang badan, panjang sayap dan panjang kaki) anakan murai batu hingga fase ranggah bulu pertama.

\section{UCAPAN TERIMA KASIH}

Penelitian ini merupakan bagian dari kegiatan hibah Penelitian Dasar multi tahun yang didanai oleh Direktorat Jenderal Penguatan Riset dan Pengembangan Kementerian Riset dan Teknologi /Badan Riset dan Inovasi Nasional (DRPM Kemenristek /BRIN) Republik Indonesia dengan nomor kontrak: 165/SP2H/AMD/LT/DRPM/2020. Tim peneliti mengucapkan terima kasih kepada DRPM Kemenristek/BRIN, LPPM Universitas Bengkulu, Jurusan Peternakan Fakultas Pertanian Universitas Bengkulu, asisten peneliti Mexi Mandela, Mei Pran Syahputra, dan Ilham Satrio Soeyono atas bantuan yang telah diberikan.

\section{DAFTAR PUSTAKA}

Anggorodi. 1995. Ilmu Makanan Ternak Umum. PT. Gramedia Pustaka Utama. 
Anonim. 2020a. Kebutuhan Protein dan Vitamin Pada Burung Peliharaan. https://www.pertanianku.com/kebutuhan-protein-danvitamin-pada-burung-peliharaan/. Diakses tanggal 8 Agustus 2020.

Anonim. 2020b. Anatomi Burung. https://id.wikipedia.org/wiki/Anatomi_bu rung. Diakses tanggal 8 Agustus 2020.

Anonim. 2019. Keistimewaan Gold Coin. https://dokumen.tips/documents/keistime waan-gold-coin-55bd1bbf9175e.html. Diakses tanggal 20 Maret 2020.

Brata, B., H. D. Putranto, J. Setianto, dan Y. Yumiati. 2019. Deskripsi manajemen pemeliharaan hewan potensial burung murai batu: studi kasus di Kota Bengkulu. Prosiding Semirata BKS-PTN Wilayah Barat Bidang Ilmu Pertanian di Fakultas Pertanian Universitas Jambi tanggal 27 - 29 Agustus 2019, hal: 647657.

Hickman, C.P., L.S. Roberts, S.L. Keen, A. Larson dan D.J. Eisenhour. 2007. Animal Diversity. Mc Graw-Hill, New York.

Jull, M.A. 1951. Poultry Husbandry. 3rd Ed. Micgraw-Hill publishing CO., Ltd.

Lambey, L.J. 2013. Kajian biologis, tingkah laku, reproduksi dan kekerabatan burung weris, Gallirallus philppensis di Minahasa Sulawesi Utara. Program Pascasarjana, IPB, Bogor.

Putranto, H.D., B. Brata, dan Y. Yumiati. 2020a. Ex-situ population of white-rumped shama (Copsychus malabaricus): Studies of density, distribution and bird keepers in Bengkulu, Sumatera. Biodiversitas 21 (3): $865-874$.

Putranto, H.D., B. Brata, dan Y. Yumiati. 2020b. Kajian ranggas bulu pertama trotol murai batu (Copsychus malabaricus) pada pemeliharaan intensif. Prosiding Webinar Nasional 2020 Persepsi "Kontribusi Usaha Ternak Lokal Sebelum dan Sesudah Pandemi Dalam Memenuhi Protein Hewani Di Indonesia", tanggal 29 Mei 2020, hal: 38-44.

Putranto, H.D., B. Brata, dan Y. Yumiati. 2019a. Profil dan populasi peternak murai batu di Kota Bengkulu. Prosiding Semirata BKS-PTN Wilayah Barat Bidang Ilmu Pertanian di Fakultas Pertanian Universitas Jambi tanggal $27-29$ Agustus 2019, hal: 1225-1234.

Putranto, H.D., B. Brata, dan Y. Yumiati. 2019b. Ex-situ population of white-rumped shama: Density, distribution and bird fanciers. Prosiding International Conference on Biodiversity Society for Indonesian Biodiversity (SIB) Mataram, Indonesia, 14-15 December 2019, hal: 123.

Putranto, H. D., D. Okvianto, dan H. Prakoso. 2018. Reproductive studies on murai batu (Copsychus malabaricus) in Bengkulu local captive breeding. Jurnal Sain Peternakan Indonesia 13 (2): 130139.

Prayoga, B. 2015. Kupas Tuntas Budidaya Kroto Cara Modern. Penebar Swadaya.

Radiopoetro. 1986. Zoology. Cetakan 3. Percetakan Erlangga.

Rose, S.P. 1997. Principle of Poultry Science. Centre for Agriculture and Bioscience International, New York.

Saraswati, T.R., S. Tana, E.Y.W. Yuniwarti. 2018. Morphologycal description of Javanese Celepuk Female (Otus angelina). Buletin Anatomi dan Fisiologi 3 (1): 110-115. 